\title{
Letter to the editor: "Update in native tissue vaginal vault prolapse repair"
}

\author{
Karen Ruben Husby ${ }^{1,2}$ (D) Gunnar Lose ${ }^{1,2} \cdot$ Niels Klarskov $^{1,2}$ \\ Received: 9 July 2020 / Accepted: 27 July 2020 / Published online: 21 August 2020 \\ (C) The International Urogynecological Association 2020
}

Dear Editor,

We read with interest the clinical opinion "Update in native tissue vaginal vault prolapse repair" [1] and share the authors' dedication to prove the best surgical technique for treating vaginal vault repair. We agree that "safety and efficacy" grants special focus. Therefore, we are a bit surprised to learn that the authors recommend iliococcygeus fixation (ICF) based on the statement that "no randomized trials and few case series have analysed the efficacy and safety of this procedure".

We welcome further evaluation of the technique in the treatment of women with vaginal vault prolapse; however, this should be done in a controlled fashion according to international guidelines and acknowledged principles for the launching of new surgical techniques (e.g. IUGA or EAU) to secure the safety of our patients.

In Denmark, we experienced a sudden popularity of a newly implemented operation technique, sacrospinous ligament hysteropexy (SH), beginning in 2010. Data were harvested from the Danish Urogynaecological Database [2]. When we evaluated the technique in 2019 we found a 40.2 times higher risk of reoperation in the apical compartment after SH (confidence interval [CI]: 21.6-74.7) than after the Manchester operation and a 8.6 times higher risk (CI: 6.0-12.1) than after vaginal hysterectomy [3].

It is important to remember some lessons from the mesh era, namely:

Karen Ruben Husby

Karen.ruben.husby.02@regionh.dk

1 Department of Obstetrics and Gynecology, Herlev and Gentofte University Hospital, Borgmester Ib Juuls Vej 1,

2730 Herlev, Denmark

2 University of Copenhagen, Copenhagen, Denmark
1. The danger of implementing new surgical techniques without sufficient knowledge about safety and efficacy

2. The ethical demand for a full and extended informed consent to surgery when the evidence is limited

\section{Compliance with ethical standards}

Conflicts of interest K.R. Husby and G. Lose have no disclosures. N. Klarskov has received travel grants from Contura International A/S outside the study.

\section{References}

1. Braga A, Serati M, Salvatore $S$, et al. Update in native tissue vaginal vault prolapse repair. Int Urogynecol J. 2020. https://doi.org/10. 1007/s00192-020-04368-4.

2. Husby KR, Lose G, Klarskov N. Trends in apical prolapse surgery between 2010 and 2016 in Denmark. Int Urogynecol J. 2020;31: 321-7. https://doi.org/10.1007/s00192-018-3852-7.

3. Husby KR, Larsen MD, Lose G, Klarskov N. Surgical treatment of primary uterine prolapse: a comparison of vaginal native tissue surgical techniques. Int Urogynecol J. 2019;30:1887-93. https://doi. org/10.1007/s00192-019-03950-9.

Publisher's note Springer Nature remains neutral with regard to jurisdictional claims in published maps and institutional affiliations. 